\title{
Biological Test for Triazine Efficacy Eradication of Pathogenic Bacteria, Ranyah, KSA
}

\section{Sherifa Mostafa M. Sabra}

Senior Const., Asst. Prof., Dr., Microbiology, Technology and Science Dept., Ranyah College, Taif University, KSA.

Corresponding Author: Sherifa Mostafa M. Sabra. Asst. Prof., Dr., Microbiology, Technology and Science Dept., Ranyah University College, Taif University, KSA.

Received date: January 01, 2021; Accepted date: January 05, 2021; Published date: February 02,2021

Citation: Sherifa M. M. Sabra (2021) Biological Test for Triazine Efficacy Eradication of Pathogenic Bacteria, Ranyah, KSA. J, Biotech. and Bioprocessing 2(2); DOI: 10.31579/2766-2314/023

Copyright: (C) 2021, Sherifa Mostafa M. Sabra, This is an open access article distributed under the Creative Commons Attribution License, which permits unrestricted use, distribution, and reproduction in any medium, provided the original work is properly cited.

\begin{abstract}
The objectives were to use triazine chemico-pharmaco complexes to test their efficacy eradication of pathogenic bacteria were Staphylococcous aureus (Staph. aureus) and Escherichia coli (E. coli). Average eradication of Staph. aureus was obvious in samples 4 and 5, followed by 2 and then 1 and 3 . The ratio were duple from the preceding one. While for $E$. coli included the fifth sample, then fourth, then first, second and third. It was quick, but not duplication, to reach complete eradication. Average turbidity degree of Staph. aureus presented in the fourth and fifth samples at $10 \mathrm{hr}$, then the second sample at $12 \mathrm{hr}$ and the rest at $14 \mathrm{hr}$. From the average turbidity degree, it turned out that the turbidity gradually disappeared and moved from one degree to another after two hours, while at $12 \mathrm{hr}$ and $14 \mathrm{hr}$ it was in the same class and reached the absence of turbidity degree at $14 \mathrm{hr}$. So long, for $E$. coli was disappeared in the fifth sample at $10 \mathrm{hr}$, followed by the fourth sample at $12 \mathrm{hr}$ and the rest at $4 \mathrm{hr}$. From the average turbidity degree, it was gradually disappeared. The present study concluded that from test results showed newly prepared of triazine chemico-pharmaco complexes displayed a good antibacterial activity by efficacy eradication of pathogenic bacteria. While also showed triazine chemico-pharmaco complexes may be a talented pattern for antibacterial activities. This research also recommended triazine chemico-pharmaco complexes may use as substitution of antibiotics against antibiotic resistant pathogenic bacteria.

Keywords: triazine chemico-pharmaco complexes, pathogenic bacteria, staph. aureus, e. coli, eradication, turbidity degree
\end{abstract}

\section{Introduction}

The chemico-pharmaco complexes had industrial a reliable in medical enquiry [1]. Triazine had considered as a safe in numerous antibacterial, secure site and were rising in nature [2]. Its complexes were significant as antibacterial as in pharmacological. They were present in produces, was thrilling had inspirational organic possessions [3]. They current in usual bases had antibacterial possessions and rising care of antibacterial for pathogenic bacteria [4]. They had seemed increasing of antibacterial fight bacteria; so they replaced as substructures [5]. They had significant part in therapeutic interaction due to organic actions as antibacterial. They combined heterocyclic complexes produced and partitioned for antibacterial action. As well in contradiction of Gram-positive and negative bacteria. They had presented astonishing in-vitro antibacterial in contradiction of Staph. aureus and E. coli as main pathogenic and diseases causing bacteria [1]. They reserved the strength against as antibacterial, so for Staph. aureus by observed activity decrease and decline the reset bacteria [6-7].

The objectives of this cooperative research paper were to use five triazine chemico-pharmaco complexes of the abovementioned synthetic chemical, that were to test their efficacy eradication of pathogenic bacteria (Staph. aureus and $E$. coli). It was by ability to exterminate two types of main pathogenic diseases causing bacteria. As well, it may helped to use as a chemo-pharmaceutical substance to eradicate pathogenic bacteria and as alternatives to antibiotics.

\section{Methodology}

- Preparation of chemical samples: Five samples of triazine chemico-pharmaco complexes under test had collected from "Medical Sciences Dept." with full chemical characteristics [8].

- Preparation of pathogenic bacteria: Two classified pathogenic bacterial samples under test (Staph. aureus and E. coli) had collected from "Analysis Center". The samples had cultured on "Molar Hinton Agar", and then had transferred a measured quantity to sterile tubes with a fixed amount of the triazine chemico-pharmaco complexes. The tubes had kept in the incubator for 14 hours at $37^{\circ} \mathrm{C}$ with taking samples every two hr for cultivation and monitoring eradication percentage, then recording means. The turbidity had measured in the tubes every two hours by "McFarland Standards" and recording means [9].

- Data analysis: The results averages had collected and had use "Simple Excel Program" to create tables and graphs maintaining the results [10].

\section{Results and discussion}




\begin{tabular}{|l|c|c|c|c|c|c|c|}
\hline \multirow{2}{*}{$*$ No } & \multicolumn{7}{|c|}{ Eradication \% } \\
\cline { 2 - 8 } & $\mathbf{2}$ *hr & $\mathbf{4 h r}$ & $\mathbf{6 h r}$ & $\mathbf{8 h r}$ & $\mathbf{1 0 h}$ & $\mathbf{1 2 h}$ & $\mathbf{1 4 h r}$ \\
\hline No 1 & $10 \%$ & $20 \%$ & $30 \%$ & $50 \%$ & $70 \%$ & $90 \%$ & $100 \%$ \\
\hline No 2 & $15 \%$ & $30 \%$ & $50 \%$ & $70 \%$ & $85 \%$ & $100 \%$ & $100 \%$ \\
\hline No 3 & $10 \%$ & $15 \%$ & $30 \%$ & $50 \%$ & $65 \%$ & $90 \%$ & $100 \%$ \\
\hline No 4 & $25 \%$ & $55 \%$ & $70 \%$ & $80 \%$ & $100 \%$ & $100 \%$ & $100 \%$ \\
\hline No 5 & $25 \%$ & $50 \%$ & $60 \%$ & $80 \%$ & $100 \%$ & $100 \%$ & $100 \%$ \\
\hline Mean & $\mathbf{1 7 \%}$ & $\mathbf{3 4 \%}$ & $\mathbf{4 8 \%}$ & $\mathbf{6 6 \%}$ & $\mathbf{8 4 \%}$ & $\mathbf{9 6 \%}$ & $\mathbf{1 0 0 \%}$ \\
\hline \multicolumn{7}{|l|}{ \%taph. aureus: Staphylococcous aureus, *No: Number, *hr: Hour } & \\
\hline
\end{tabular}
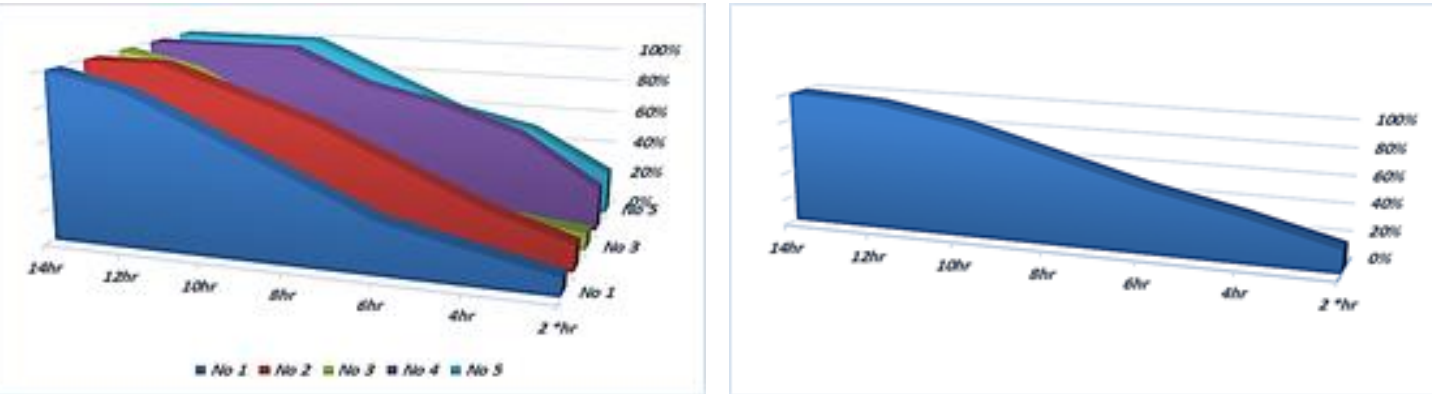

Table 1 and Graph (1 and 2). Average eradication percentages of *Staph. aureus after remain with complexes

Table 1 and graph (1 and 2) presented average eradication percentages of Staph. aureus after remain with triazine chemico-pharmaco complexes, the eradication process was evident in samples 4 and 5 , followed by sample 2 and then samples 1 and 3 . The complete eradication of bacteria was after ten $\mathrm{hr}$ for the fourth and fifth samples, it did after $12 \mathrm{hr}$ for the second sample only, and it completed after 14 hours for samples 1 and 3. From the mean, it found that the eradication ratio were doubles from the previous one, which indicated the speed of extermination of the tested triazine chemico-pharmaco complexes material for bacteria in double proportions. The result showed the extent of the effect of the triazine chemico-pharmaco complexes on bacteria. It was able to destroy it within a period of ten $\mathrm{hr}$ from the tested samples [1-7]. As well, this appeared an efficacy eradication of pathogenic bacteria, so this indicated its ability to eliminate disease-causing bacteria. Therefore, this may be an alternative to antibiotics to eliminate antibiotic resistant bacteria [1-7].

\begin{tabular}{|l|c|c|c|c|c|c|c|}
\hline \multirow{2}{*}{ *No } & \multicolumn{7}{|c|}{ Eradication $\%$} \\
\cline { 2 - 8 } & 2 *hr & $\mathbf{4 h r}$ & $6 \mathrm{hr}$ & $\mathbf{8 h r}$ & $10 \mathrm{hr}$ & $12 \mathrm{hr}$ & $14 \mathrm{hr}$ \\
\hline No 1 & $\mathbf{1 0} \%$ & $\mathbf{1 5} \%$ & $\mathbf{2 5} \%$ & $\mathbf{4 0} \%$ & $\mathbf{6 0} \%$ & $\mathbf{8 0} \%$ & $100 \%$ \\
\hline No 2 & $\mathbf{5 \%}$ & $\mathbf{2 0} \%$ & $\mathbf{4 0} \%$ & $\mathbf{5 5} \%$ & $\mathbf{7 5} \%$ & $\mathbf{9 0} \%$ & $100 \%$ \\
\hline No 3 & $\mathbf{1 5} \%$ & $\mathbf{3 0} \%$ & $\mathbf{4 5} \%$ & $\mathbf{6 0} \%$ & $\mathbf{7 5} \%$ & $\mathbf{9 0} \%$ & $100 \%$ \\
\hline No 4 & $\mathbf{2 0} \%$ & $\mathbf{4 0} \%$ & $\mathbf{6 0} \%$ & $\mathbf{8 0} \%$ & $\mathbf{9 0} \%$ & $100 \%$ & $100 \%$ \\
\hline No 5 & $\mathbf{2 0} \%$ & $\mathbf{4 5} \%$ & $\mathbf{6 5} \%$ & $\mathbf{8 0} \%$ & $100 \%$ & $100 \%$ & $100 \%$ \\
\hline Mean & $14 \%$ & $\mathbf{3 0} \%$ & $\mathbf{4 7} \%$ & $\mathbf{6 3} \%$ & $\mathbf{8 0} \%$ & $\mathbf{9 2} \%$ & $100 \%$ \\
\hline \multicolumn{7}{|c|}{ E. coli: Escherichia coli, *No: Number, *h: Hour } \\
\hline
\end{tabular}
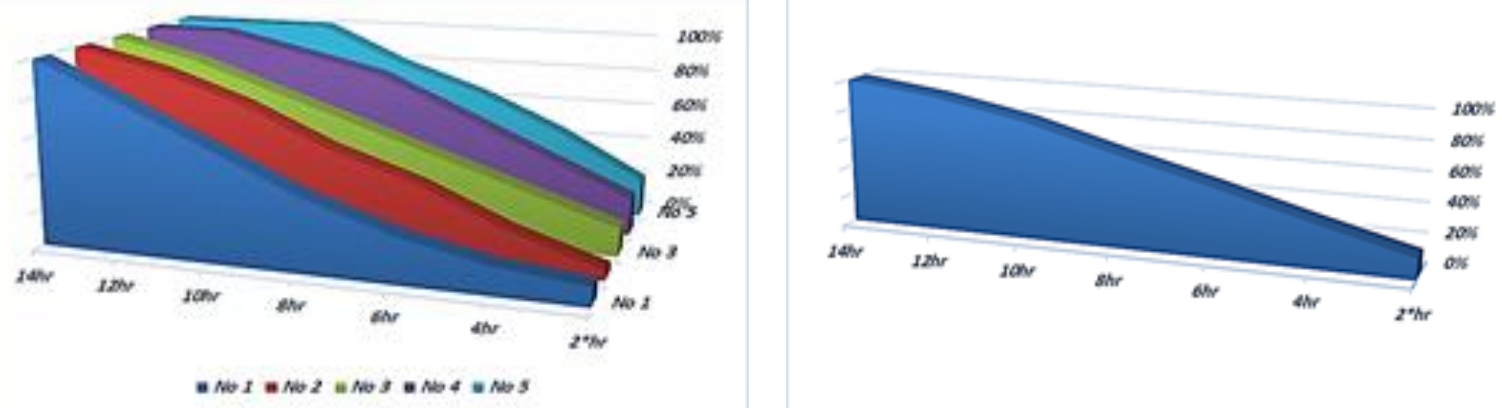

Table 2 and Graph (3 and 4). Average eradication percentages of *E. coli after remain with complexes 
Table 2 and graph ( 3 and 4 ) presented average eradication percentages of E. coli after remain with triazine chemico-pharmaco complexes, the eradication process included the fifth sample, then only the fourth in speed, then the first, second and third sample. The fifth sample was the fastest, as it completed at $10 \mathrm{hr}$, the fourth sample took place at $12 \mathrm{hr}$, and the rest were at $14 \mathrm{hr}$. From the mean, it found that the rates of eradication were quick, but not multiplying, to reach complete eradication [1-7]. Through the test, it found that the tested triazine chemico-pharmaco complexes had the ability to eradicate bacteria that causes diseases or food poisoning and may use for preserving food, so longer this could use an alternative to antibiotics. The test results proved their ability to appear an efficacy eradication of pathogenic bacteria [1-7].

\begin{tabular}{|c|c|c|c|c|c|c|c|}
\hline \multirow[t]{2}{*}{ *No } & \multicolumn{7}{|c|}{ Turbidity Degree } \\
\hline & $2 * h r$ & $4 \mathrm{hr}$ & 6hr & $8 \mathrm{hr}$ & $10 \mathrm{hr}$ & $12 \mathrm{hr}$ & 14hr \\
\hline No 1 & 4 & 4 & 3 & 2 & 1 & 1 & 0 \\
\hline No 2 & 4 & 3 & 2 & 1 & 1 & 0 & 0 \\
\hline No 3 & 4 & 4 & 3 & 2 & 2 & 1 & 0 \\
\hline No 4 & 4 & 2 & 1 & 1 & 0 & 0 & 0 \\
\hline No 5 & 4 & 2 & 2 & 1 & 0 & 0 & 0 \\
\hline Mean & 4 & 3 & 2.2 & 1.4 & 0.8 & 0.4 & $\mathbf{0}$ \\
\hline \multicolumn{8}{|c|}{ *Staph. Aureus: Staphylococcous aureus, *No: Key Number, *hr: Hour } \\
\hline
\end{tabular}

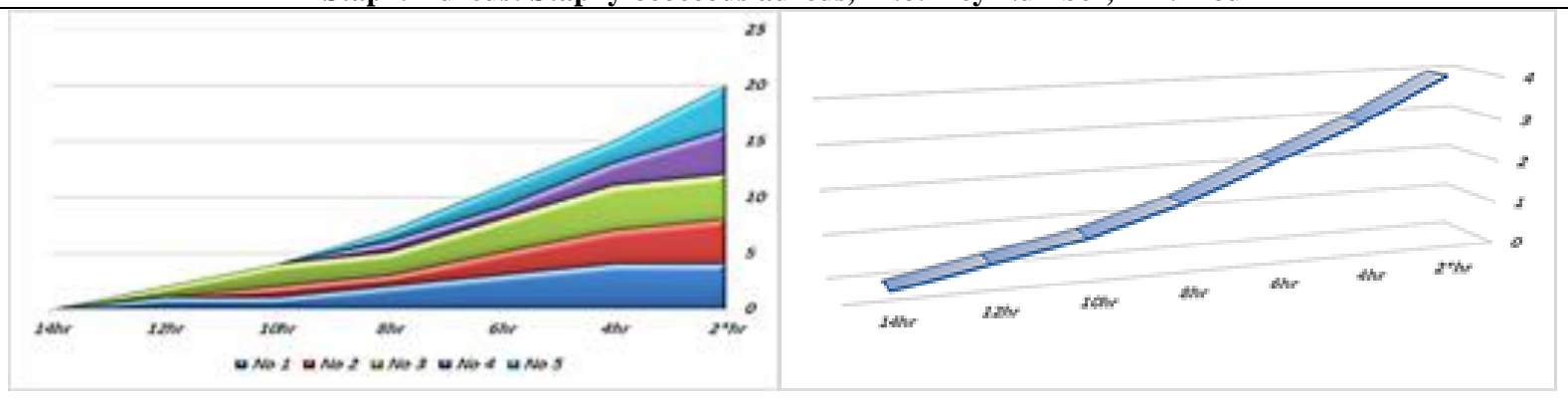

Table 3 and Graph (5 and 6). Average turbidity degree of *Staph. aureus after remain with complexes.

Table 3 and graph (5 and 6) presented average turbidity degree of Staph. aureus after remain with triazine chemico-pharmaco complexes, measuring the average turbidity degree indicated the presence of live bacteria cells in the solution. It showed through measurement that the fastest in the disappearance of turbidity, which was evidence of the death and decomposition of cells in the fourth and fifth samples at $10 \mathrm{hr}$, then the second sample at $12 \mathrm{hr}$ and the rest at $14 \mathrm{hr}$. From the average turbidity degree, it turned out that the turbidity gradually disappeared and moved

\begin{tabular}{|c|c|c|c|c|c|c|c|}
\hline \multirow[t]{2}{*}{$*$ No } & \multicolumn{7}{|c|}{ Turbidity Degree } \\
\hline & $2 * \mathrm{hr}$ & $4 \mathrm{hr}$ & $6 \mathrm{hr}$ & $8 \mathrm{hr}$ & 10hr & $12 \mathrm{hr}$ & $14 \mathrm{hr}$ \\
\hline No 1 & 4 & 4 & 4 & 3 & 2 & 1 & 0 \\
\hline No 2 & 4 & 4 & 3 & 2 & 1 & 0 & 0 \\
\hline No 3 & 4 & 3 & 3 & 2 & 1 & 0 & 0 \\
\hline No 4 & 4 & 3 & 2 & 1 & 0 & 0 & 0 \\
\hline No 5 & 4 & 3 & 2 & 1 & 0 & 0 & 0 \\
\hline Mean & 4 & 3.4 & 2.8 & 1.8 & 0.8 & 0.2 & $\mathbf{0}$ \\
\hline \multicolumn{8}{|c|}{ *E. coli: Escherichia coli, *No: Number, *hr: Hour } \\
\hline
\end{tabular}

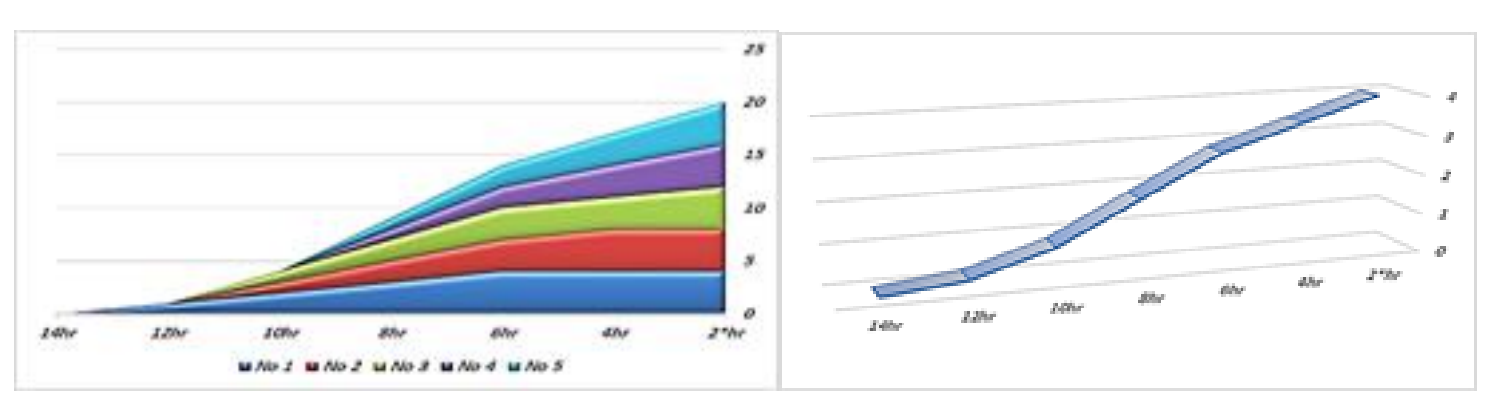

from one degree to another after two hours, while at $12 \mathrm{hr}$ and $14 \mathrm{hr}$ it was in the same class and reached the absence of turbidity degree at $14 \mathrm{hr}$ [17]. The disappearance of turbidity degree was the largest evidence of bacterial cell death and decomposition, which proved that the triazine chemico-pharmaco complexes carried out cell death and decomposition, and this proved their role in antibacterial, so they could use as an alternative to antibiotics [1-7]. 
Table 4 and graph ( 7 and 8) presented average turbidity degree of $E$. coli after remain with triazine chemico-pharmaco complexes, turbidity degree of bacterial cells disappeared in the fifth sample at $10 \mathrm{hr}$, followed by the fourth sample at $12 \mathrm{hr}$ and the rest were at $4 \mathrm{hr}$. From the average turbidity degree, it was gradually disappeared [1-7]. From the results, the ability of the triazine chemico-pharmaco complexes to eliminate bacteria confirmed. It can prove that they had antibacterial properties, as well as an efficacy eradication of pathogenic bacteria [1-7].

\section{Conclusions}

The present study showed that newly prepared of triazine chemicopharmaco complexes showed good antibacterial activity by efficacy eradication of pathogenic bacteria. While also showed triazine chemicopharmaco complexes may be a talented pattern for antibacterial activities.

\section{Recommendation}

Triazine chemico-pharmaco complexes may use as substitution of antibiotics against antibiotic resistant bacteria.

\section{Acknowledgment}

Many thank sent to "Medical Sciences Dept." and "Analysis Center" for sending triazine chemico-pharmaco complexes and pathogenic bacteria (Staph. aureus and E. coli) to conduct an antibacterial experiment.

\section{Future works}

It is hope to conduct experimentally antibacterial effects of triazine chemico-pharmaco complexes as chemical or pharmacological derivatives.

\section{Fundus}

It was from authors.

\section{Conflict of interest}

It had declared no conflict of interest.

\section{References}

1. Rajeesh, k., Koti, E., Ayyiliath, S. and Karickal, H., (2018). Synthesis, characterization and structure activity relationship (SAR) studies of differently substituted naphthalene and triazine incorporated heterocyclic molecule as possible anti-bacterial and anti-fungal agents. Am. J. Clin. Micro. Antimicro. 1(5): Article 1024.

2. Zhou, C., Min, J., Liu, Z., Young, A., Deshazer, H., Gao, T. and Kallenbach, R., (2008). Synthesis and biological evaluation of novel 1, 3, 5-triazine derivatives as antimicrobial agents. Bioorg. Med. Chem. Lett., 18(4):1308-11.

3. Marella, A., Tanwar, P., Saha, R., Ali, R., Srivastava, S. and Akhter, M., (2013). Quinoline: A versatile heterocyclic. Saudi Pharm. J., 21(1):1-12.

4. Sojib, Z., Mohammed, H., Rachel, N., Varshil, M., Kazi, T. and Naznin, H., (2017). A Review on antibiotic resistance: Alarm bells are ringing. Cureus, 9(6):e1403.

5. Julian, D. and Dorothy, D., (2010). Origins and evolution of antibiotic resistance. Micro. Mol. Bio. Rev., 74(3):417-433.

6. Chadotra, N. and Baldaniya, B., (2019). Synthesis and characterizations of some new 1, 3, 5-triazine-2, 4, 6-Triamine based derivatives as potent antimicrobial and antiinfective Agents. Int. J. Sci. Res. In Chemistry (IJSRCH), 4(1):29-38.

7. Heba, H., Abd El-Galil, A., Eman, N., Elsayed, E. and Eman, A., (2020). Synthesis, antimicrobial activity and molecular docking of novel thiourea derivatives tagged with thiadiazole, imidazole and triazine moieties as potential DNA gyrase and topoisomerase IV inhibitors. Molecules, 25:2766.

8. Bielenica, A., Stefa 'nska, J., St epie 'n, K., Napiórkowska, A., Augustynowicz-Kope'c, E., Sanna, G., Madeddu, S., Boi, S., Giliberti, G. and Wrzosek, M., (2015). Synthesis, cytotoxicity and antimicrobial activity of thiourea derivatives incorporating 3(trifluoromethyl) phenyl moiety. Eur. J. Med. Chem., 101:111125.

9. Ashraf, M., Abdulaziz, A., Khalid, A., Turki, D., Essam, S. and Marwah, B., (2018). Antimicrobial activity of some plant extracts against bacterial strains causing food poisoning diseases. Saudi J. Biol. Sci., 25(2):361-366.

10. https://www.microsoft.com/en-us/microsoft-365/excel.2020
This work is licensed under Creative Commons Attribution 4.0 License
To Submit Your Article Click Here: Submit Manuscript

DOI: $10.31579 / 2766-2314 / 023$
Ready to submit your research? Choose Auctores and benefit from:

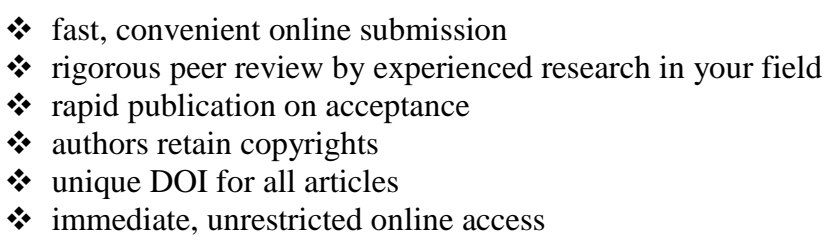

At Auctores, research is always in progress.

Learn more www.auctoresonline.org/journals/biotechnology-andbioprocessing- 